Journal of Management and Bussines (JOMB)

Volume 1, Nomor 1, Juni 2019

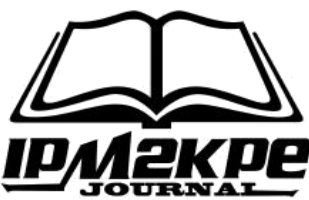

$p$-ISSN : 2656-8918

e-ISSN: 2684-8317

DOI : https://doi.org/10.31539/jomb.v1i1.654

\title{
PENGARUH MOTIVASI DAN DISIPLIN KERJA TERHADAP KINERJA KARYAWAN
}

\author{
M. Effendi ${ }^{1}$, Febrie Yogie ${ }^{2}$ \\ Sekolah Tinggi Ilmu Ekonomi Musi Rawas Lubuklinggau ${ }^{1,2}$ \\ Email:m.effendi1969@gmail.com ${ }^{1}$
}

\begin{abstract}
ABSTRAK
Penelitian ini dilakukan untuk mengetahui pengaruh motivasi dan disiplin kerja terhadap kinerja karyawan Division 03 PT. PP London Sumatera Indonesia Tbk. Bukit Hijau Kecamatan Rawas Ilir Kabupaten Musi Rawas Utara. Dalam penelitian ini digunakan metode kuisioner tiga item variabel yaitu kuisioner motivasi $\left(\mathrm{X}_{1}\right)$, disiplin kerja $\left(\mathrm{X}_{2}\right)$ dan variabel kinerja karyawan $(\mathrm{Y})$. Teknik analisis data yang digunakan adalah Analisis Regresi Linier Berganda, Koefisien Determinasi $\left(\mathrm{R}^{2}\right)$, dan Uji F. Hasil penelitian, dari hasil analisis regresi linier berganda diperoleh persamaan $\mathrm{Y}=10,428+$ $0,349 X_{1}+0,382 X_{2}$. Selanjutnya dari analisis diperoleh nilai $R$ square $R^{2}$ sebesar 0,770 atau $77,0 \%$. Nilai tersebut memberi pengertian bahwa motivasi $\left(\mathrm{X}_{1}\right)$, dan disiplin kerja $\left(\mathrm{X}_{2}\right)$ memberikan sumbangan pengaruh sebesar 77,0\% terhadap kinerja karyawan (Y). Sedangkan sisanya sebesar $23,0 \%$ dipengaruhi oleh variabel yang lain yang tidak masuk dalam penelitian ini. Simpulan, terdapat pengaruh secara simultan antara motivasi dan disiplin kerja terhadap kinerja karyawan
\end{abstract}

Kata Kunci : Motivasi, Disiplin Kerja, Kinerja

\begin{abstract}
This research was conducted to determine the effect of motivation and work discipline on the performance of Division 03 employees of PT. PP London Sumatra Indonesia Tbk. Bukit Hijau Rawas Ilir District, North Musi Rawas Regency. In this study used a three item variable questionnaire method namely motivation questionnaire (X1), work discipline (X2) and employee performance variable (Y). The data analysis technique used is the Analysis of Multiple Linear Regression, Coefficient of Determination (R2), and Test $F$. The results of the study, from the results of multiple linear regression analysis the equation $Y=10.428+0.349 X 1+0.382 X 2$. Furthermore, from the analysis obtained the $R$ square $R 2$ value of 0.770 or $77.0 \%$. This value gives the understanding that motivation (X1), and work discipline (X2) contribute $77.0 \%$ to employee performance $(Y)$. While the remaining $23.0 \%$ is influenced by other variables not included in this study. Conclusion, there is a simultaneous influence between motivation and work discipline on employee performance
\end{abstract}

Keywords: Motivation, Work Discipline, Performance 


\section{PENDAHULUAN}

Sumber daya manusia dalam suatu organisasi perusahaan adalah suatu kesatuan yang tidak dapat dipisahkan. Perusahaan dapat berjalan sesuai dengan harapan apabila didalamnya terdapat manusia-manusia dengan satu tujuan yang sama yaitu berkeinginan untuk menjadikan organisasi tempat dia bekerja dan mencari nafkah mengalami peningkatan keuntungan serta perkembangan dari tahun ke tahun. Apabila tujuan dan keinginan itu dapat terwujud, maka sumber daya manusia tersebut tentu hasil jerih payahnya mendapatkan balasan dengan nilai yang sesuai dari organisasi yang telah di perjuangankannya selama ini.

Salah satu aspek yang memiliki pengaruh penting dalam menentukan baik dan buruknya kinerja karyawan adalah disiplin kerja dan motivasi. Faktor tersebut bisa saja bersumber dari organisasi, dari kayawan maupun dari faktor luar karyawan dan organisasi. Untuk faktor yang bersumber dari karyawan, salah satu diantaranya adalah sikap atau tingkah laku karyawan yang diimplementasikan dalam bentuk disiplin.

Menurut Armstrong (Priansa, 2016) menyatakan bahwa motif adalah alasan untuk melakukan sesuatu. Motivasi berkaitan dengan kekuatan dan arah perilaku dan faktor-faktor yang mempengaruhi seseorang untuk berprilaku dengan cara tertentu.

Disamping motivasi, salah satu hal yang harus diperhatikan untk meningkatkan kinerja karyawan adalah dengan disiplin kerja karyawan. Disiplin mencoba untuk mencegah kerusakan atau kehilanganharta benda, mesin, peralatan, dan perlengkapan kerja yang disebabkan oleh ketikhati-hatian, senda gurau atau pencurian.

Dengan kedisiplinan karyawan dapat lebih bertanggung jawab terhadap tugasnya sehingga kinerja akan lebih baik, karyawan yang memiliki disiplin akan memilki kinerja yang lebih baik, Untuk menunjang Kinerja suatau perusahaan diperlukan motivasi dan disiplin kerja karyawan. Terkait dengan pencapaian Kinerja yang baik. Maka manajemen perlu memperhatikan faktor-faktor apa sajakah yang dapat meningkatkan dan mempertahankan kinerja karyawan. Sebab kinerja karyawan tidak serta merta timbul tanpa adanya rencana yang baik dari manajemen untuk mewujudkannya.

Kinerja adalah hasil kerja yang dapat dicapai oleh seseorang atau sekelompok orang dalam suatu organisasi, sesuai dengan wewenang dan tanggungjawab masingmasing, dalam rangka upaya mencapai tujuan organisasi bersangkutan secara legal, 
tidak melanggar hukum dan sesuai dengan moral dan etika. Dapat disimpulkan bahwa Kinerja adalah perbandingan antara hasil yang dicapai dengan sumber daya yang digunakan serta berkaitan erat dengan efektivitas dan efisiensi, yang dimana menunjukkan tingkat kemampuan karyawan untuk mencapai tujuan organisasi.

PT. PP. London Sumatra Indonesia Tbk. bukit hijau Kecamatan Rawas ilir Kabupaten Musi Rawas Utara, Bukit hijau Estate adalah salah satu kebun lonsum yang berlokasi di Kabupaten Musi Rawas Utara Provinsi Sumatra Selatan. Jarak kebun dari kota lubuklinggau kurang lebih sekitar 150 kilometer atau memerlukan waktu tempuh kurang lebih 3 jam lewat transportasi darat. Bukit hijau Estate pertama kali beroperasi pada tahun 1998 dengan komoditas utamnya adalah tanaman Kelapa sawit.

Berdasarkan fakta yang ada saat melakukan observasi, dalam hal ini peneliti mengamati bahwa saat ini kinerja karyawan division 03 masih kurang maksimal, karena hasil kerja karyawan belum sesuai harapan perusahaan.

Dari kenyataan yang ada dilapangan dilihat dari Motivasi Manajer dan Asisten sudah cukup baik dalam memberikan motivasi kepada para karyawan, dilihat dari setiap hari manajer atau asisten memberikan masukan kepada karyawannya agar bisa bekerja secara optimal. Tetapi ketika Atasan atau mandor tidak ada dilapangan masi ada sebagian karyawan kurang bersemangat dalam bekerja sehingga pekerjaan yang dilakukannya tidak terlaksanakan dengan baik.

Kemudian dilihat dari Disiplin kerja karyawan masi dikatakan kurang baik. Hal ini dilihat dari tingkat kehadiran dan ketepatan waktu datang dan pulang kerja. Metode absensi sudah mengunakan absensi sidik jari (finger), sehingga bisa dilihat tepat dan akurat dalam hal menilai para karyawan. Sehingga dapat diartikan disiplin kerja karyawan PT.PP londom Sumatra Indonesia bukit hijau devision 03 masih kurang baik.

\section{KAJIAN TEORI}

\section{Motivasi}

Motivasi berasal dari kata latin "Movere" yang berarti dorongan, daya pengerakkekuatan yang menyebabkan suatu tindakan atau perbuatan. Kata " Movere “ dalam bahasa inggris sering disepadankan dengan "Motivacion" yang berarti pemberian motif, penimbulan motif, atau hal yang menimbulkan dorongan atau keadaan yang menimbulkan dorongan. 
Menurut Hamali (2016) prinsip-prinsip dalam memotivasi kerja karyawan, yaitu : a) prinsip partisipasi, b) prinsip komunikasi, c) prinsip mengakui adil bawahan, d) prinsip pendelegasian wewenang, e) prinsip member perhatian. Diberikannya motivasi kepada karyawan atau seseorang tentu saja mempuanyai tujuan antara lain; a) mendorong gairah dan semangat karyawan, b) menigkatkan moral dan kepuasan kerja, c) meningkatkan produktivitas kerja karyawan, d) mempertahankan loyalitas dan kestabilan karyawan, e) meningkatkan kedisiplinan dan menurunkan tingkat absensi karyawan, f) menciptakan suasana dan hubunngan kerja yang baik, g) meningkatkan kreativitas dan partisipasi karyawan, h) meningkatkan kesejatteraan karyawan, i) mempertinggi rasa tanggung jawab karyawan terhadap tugas dan pekerjaannya.

Tahapan motivasi dilihat dari teori Hierarki Menurut Abraham H. maslow. (Fahmi, 2014), sebagai berikut; a) physiological needs (kebutuhan fisiologis), b) safety and security needs (kebutuhan rasa aman), c) social needs (kebutuhan sosial), d) esteem needs (kebutuhan harga diri atau pengakuan), e) self-actualization needs (kebutuhan aktualisasi diri). Menurut McClelland (dalam darmawan, 2013) motivasi kerja adalah segala sesuatu yang mendorong seorang karyawan melaksanakan tugas-tugasnya guna mencapai tujuan yang diinginkan.

Berikut indikator-indikator motivasi, yaitu : a) kebutuhan terhadap prestasi, maksudnya, kebutuhan anggota-anggota organisasi untuk bekerja dengan baik dan berprestasi di organisasi; 1) adanya perasaan terkait dengan bidang tugasnya, 2) berusaha mengatahui prestasinya dan memperoleh umpan balik, 3) tanggap terhadap situasi sukar dan menentang, 4) keinginan menerima tanggung jawab, 5) standar prestasi kerja yang dapat diukur dan terpenuhi, b) kebutuhan terhadap kekuasaan. artinya, kebutuhan anggota organisasi untuk mendapatkan kekuasaan dan mendapat penghargaan orang lain; 1) senang berargumentasi yang baik, 2) mencari posisi wewenang yang dapat memberikan perintah, 3) pentingnya simbol status ntuk mempengaruhi orang lain, c) kebutuhan terhadap afiliasi. Maksudnya, kebutuhan anggota organisasi untuk bekerja sama dengan orang lain; 1) senang bekerja sama dengan orang lain, 2) berinteraksi dengan karyawan lain dan bersahabat dengan karyawan baru, 3) kesediaan membantu orang lain. 


\section{Disiplin Kerja}

Disiplin adalah kegiatan manajemen untuk menjalankan standar-standar organisasional. Keteraturan adalah ciri utama organisasi dan displin adalah salah satu metode untuk nenelihara keteraturan tersebut. Disiplin mencoba untuk mencegah kerusakan atau kehilangan harta benda, mesin, peralatan, dan perlengkapan kerja yang disebabkan oleh ketikhati-hatian, senda gurau atau pencurian.

Ada beberpa prinsip yang seharusnya menjadi pedoman kita dalam mengambil tindakan disipliner Menurut Becal (Sinambela, 2012), yaitu: 1) mengambil tindakan disipliner harus sesuai dengan hukum setempat dan perjanjian perburuhan yang berlaku; 2) semua tindakan disipliner harus didokumentasikan secara lengkap, secara mendetail kekurangan yang sebenarnya dalam kinerja, bagaimana hal itu dikomunikasikan kepada karyawan yang bersangkutan, dan langkah-langkah yang telah diambil untuk memecahkan masalah itu; 3) tindakan disipliner yang diambil hendaknya menggunakan tingkat paksaan dan tekanan terendah yang diperlukan untuk memecahkan masalah kinerja; 4) semakin besar tingkat pemaksaan yang digunakan, semakin kecil kemungkinan untuk mencapai win-win solution yang konstruktif dan tahan lama; 5) semakin kita mampu menggambarkan dengan jelas permasalahan kinerja yang terjadi, semangkin kita dapat memecahkannya bersama karyawan yang bersangkutan, dan semakin besar pula perlindungan hukum yang kita dapatkan bila kita terpaksa mengambil tindakan disipliner yang keras.

Fungsi disiplin kerja dari kegunaan disiplin dalam organisasi Menurut Sinambela (2012) dapat diperhatikan dalam empat perfektif, yaitu restributif, korektif, hak-hak individual, dan ultitarian.

Disiplin kerja dilihat dari proses tindakan disipliner Menurut Simamora (Sinambela, 2012), adalah dinamika dan berkelanjutan. Mengigat tindakan-tindakan karyawan dapat mempengaruhi yang lain dalam kelompok kerja, maka penerapan tindakan disipliner yang tepat membantu perkembangan perilaku-perilaku yang dapat diterima oleh anggota-anggota kelompok. Sebalinya, pelaksanaan tindakan disiplin yang tidak tepat memiliki efek yang merusak karyawan dalam kelompok lainnya.

Menurut (Siagian, 2013), pendisiplinan harus diterapkan secara bertahap. Yang dimaksud secara bertahap adalah dengan mengambi berbagai langkah berifat pendisiplinan, mulai dari yang paling ringan hingga kepada yang terberat. Misalnya 
dengan: a) peringatan lisan oleh penyelia, b) peryataan tertulis ketidakpuasan oleh aturan langsung, c) penundaan kenaikan gaji berkala, d) penundaan kenaikan pangkat, e) pembebasan dari jabatan, f) pemberhentian sementara, g) pemberhentian atas permintaan sendiri, h) pemberhentian dengan hormat, atas permintaan sendiri, dan, i) pemberhentian dengan tidak hormat.

Menurut Handoko, (Hamali, 2016). Indikator-indikator disiplin kerja terdiri dari; a) disiplin preventif, b) disiplin korektif, c) disiplin progresif. Menurut Sutrisno (Hamali, 2016) faktor-faktor yang mempengaruhi disiplin kerja yaitu : a) besar kecilnya pemberian kompensasi, b) ada tidaknya keteladanan pimpinan dalam organisasi, c) ada tidaknya aturan pasti yang dapat dijadikan pegangan, d) keberanian pimpinan dalam mengambil tindakan, e) ada tidaknya pengawasan pimpinan, f) ada tidaknya perhatian kepada para pegawai, g) diciptakan kebiasaan-kebiasaan yang mendukung tegaknya disiplin.

\section{Kinerja}

Kinerja adalah hasil yang diperoleh oleh suatu organisasi baik organisasi tersebut bersifat profit oriented dan non profit oriented yang dihasilkan selama satu periode tertentu. Secara lebih lebih tegas Amstrong dan Baron dalam Fahmi (2014) Kinerja merupakan hasil yang mempunyai hubungan kuat dengan tujuan strategis organisasi, kepuasan konsumen dan memberikan kontribusi ekonomi. Lebih jauh Indra Bastian menyatakan bahwa kinerja adalah gambaran mengenai tingkat pencapaian pelaksanaan suatu kegiatan /program/kebijaksanaan dalam mewujudkan sasaran, tujuan, misi dan visi organisasi yang tertuang dalam perumusan skema strategis (strategic planning) suatu organisasi (Fahmi, 2014).

Menurut Kirkpatrick dalam Wibowo (2012), terdapat delapan karakteristik yang membuat suatu standar kinerja efektif, yaitu sebagai berikut: a) standar didasarkan pada pekerjaan, b) standar dapat dicapai, c) standar dapat dipahami, d) standar disepakati, e) standar itu spesifik dan sedapat mungkin terukur, f) standar berorientasi pada waktu, g) standar harus tertulis, h) standar dapat berubah. Indikator kinerja pegawai menurut Wibowo (2012) yaitu sebagai berikut : a) tujuan, b) standar, c) umpan balik, d) alat atau sarana, e) kompetensi, f) motif, g) peluang 


\section{METODE PENELITIAN}

Populasi dalam penelitian ini adalah seluruh karyawan PT.PP London Sumatra Indonesia Tbk. Bukit Hijau Estate Division 03 Kecamatan Rawas Ilir Kabupaten Musi Rawas Utara. Yang bejumlah 31 orang karyawan. Teknik penentuan sampel dalam penelitian ini adalah dengan menggunakan sampel jenuh. Sampel jenuh adalah teknik penentuan sampel apabila semua anggota populasi digunakan sebagai sampel. Jadi sampel yang digunakan dalam penelitian ini sebanyak 31 orang responden.

Teknik pengumpulan data yang akan dipergunakan dalam penelitian ini adalah; 1) observasi, pengumpulan data dengan cara melakukan pengamatan langsung terhadap semua kegiatan yang dilakukan instansi yang akan diteliti, 2) kuisioner, pengumpulan data dengan cara membagikan kuisioner kepada responden, 3) dokumentasi, dengan cara mencatat keterangan dan dokumen yang resmi. Tekhnik ini digunakan dalam rangka mendukung data yang diperoleh baik melalui observasi maupun kuesioner.

Model analisa yang di gunakan peneliti dalam permasalahan yang ada dalam penelitian ini adalah untuk membuktikan ada atau tidaknya hubungan fungsional atau hubungan kuasal antara dua variabel bebas atau lebih dengan satu variabel terikat.

$$
\mathrm{Y}=\mathrm{a}+\mathrm{b}_{1} \mathrm{X}_{1}+\mathrm{b}_{2} \mathrm{X}_{2}
$$

Dimana :

$$
\begin{aligned}
& \mathrm{Y}=\text { Kinerja karyawan } \\
& \mathrm{X}_{1}=\text { Motivasi } \\
& \mathrm{X}_{2}=\text { Displin Kerja } \\
& \mathrm{a}=\text { Titik Potong } \\
& \mathrm{b}_{1}, \mathrm{~b}_{2}=\text { Koefisien Regresi }
\end{aligned}
$$

Analisis regresi berganda adalah meramalkan bagaimana keadaan naik turunnya variabel dependen, bila dua atau lebih variabel independen sebagai faktor predicator dimanipulasi (dinaik turunkan nilainya) (Sugiyono, 2014). Koefisien determinasi $\left(\mathrm{R}^{2}\right)$ pada intinya mengukur seberapa jauh kemampuan model dalam menerangkan variasi variabel bebas (dependen). Formulasi persamaan uji korelasi ganda adalah sebagai berikut:

$\mathbf{R y} \cdot \mathbf{x 1} \mathbf{x} \mathbf{x}=\sqrt{\frac{\left(r y x_{1}\right)^{2}+\left(r y x_{2}\right)^{2}-2 \cdot\left(r x y_{1}\right) \cdot\left(r y x_{2}\right) \cdot\left(r x_{1} x_{2}\right)}{1-\left(r x_{1} x_{2}\right)}}$

Dimana : 
$\mathrm{Ry} \cdot \mathrm{X} 1, \mathrm{X}_{2}$ : korelasi variabel $\mathrm{X}_{1}$ dengan $\mathrm{X}_{2}$ secara bersama-sama

ryx $_{1}$ : korelasi sederhana antara $\mathrm{X}_{1}$ dengan $\mathrm{Y}$

$\operatorname{ryx}_{2}$ : korelasi sederhana antara $X_{2}$ dengan $Y$

$\mathrm{rx}_{1} \mathrm{X}_{2}$ : korelasi sederhana antara $\mathrm{X}_{1}$ dengan $\mathrm{X}_{2}$

Uji $\mathrm{F}$ dilakukan untuk menguji signifikansi dengan membandingkan $\mathrm{F}_{\text {hitung }}$ dengan $\mathrm{F}_{\text {tabel, }}$, dengan rumus :

$$
\mathrm{F}_{\text {hitung }}=\frac{R^{2}(n-m-1)}{m\left(1-R^{2}\right)}
$$

Dimana :

$\mathrm{R}^{2} \quad$ : Nilai Regresi

m : Jumlah variabel bebas

n : Jumlah responden

\section{HASIL PENELITIAN}

\section{Hasil Uji Regresi Linier Berganda}

Tabel 1

Hasil Analisis Regresi Linier Berganda

\begin{tabular}{|c|c|c|c|c|c|}
\hline \multicolumn{6}{|c|}{ Coefficients $^{\mathbf{a}}$} \\
\hline \multirow[b]{2}{*}{ Model } & \multicolumn{2}{|c|}{$\begin{array}{l}\text { Unstandardized } \\
\text { Coefficients }\end{array}$} & \multirow{2}{*}{$\begin{array}{c}\begin{array}{c}\text { Standardized } \\
\text { Coefficients }\end{array} \\
\text { Beta }\end{array}$} & \multirow[b]{2}{*}{$\mathrm{T}$} & \multirow[b]{2}{*}{ Sig. } \\
\hline & B & Std. Error & & & \\
\hline 1 (Constant & 10.428 & 3.160 & & 3.300 & .003 \\
\hline $\mathrm{X} 1$ & .349 & .088 & .527 & 3.986 & .000 \\
\hline $\mathrm{X} 2$ & .382 & .121 & .416 & 3.148 & .004 \\
\hline
\end{tabular}

Berdasarkan hasil perhitungan regresi, maka diperoleh nilai $b_{1}=0,349$ dan $\mathrm{b}_{2}=0,382$ sedangkan nilai $\mathrm{a}=10,428$. Kemudian nilai tersebut dimasukkan kedalam persamaan regresi linear berganda sebagai berikut :

$$
\begin{aligned}
& Y=a+b_{1} X_{1}+b_{2} X_{2} \\
& Y=10,428+0,349 X_{1}+0,382 X_{2}
\end{aligned}
$$

\section{Hasil Uji Koefisien Determinasi $\left(\mathbf{R}^{2}\right)$}

Tabel 2

Hasil Analisis Regresi Determinan $\left(\mathbf{R}^{2}\right)$

Model Summary

\begin{tabular}{llrrr}
\hline Model & R & R Square & $\begin{array}{c}\text { Adjusted R } \\
\text { Square }\end{array}$ & $\begin{array}{l}\text { Std. Error of } \\
\text { the Estimate }\end{array}$ \\
\hline 1 & $.877^{\mathrm{a}}$ & .770 & .753 & 2.048 \\
\hline a. Predictors: (Constant), X2, X1
\end{tabular}


Dari tabel diatas diperoleh angka $\mathrm{R}^{2}$ sebesar 0,770 atau 77,0\%. Nilai tersebut memberi pengertian bahwa Motivasi $\left(\mathrm{X}_{1}\right)$ dan Disiplin Kerja $\left(\mathrm{X}_{2}\right)$ memberikan sumbangan pengaruh sebesar 0,770 terhadap Kinerja Karyawan (Y). Sedangkan sisanya sebesar 23,0\% dipengaruhi oleh variabel yang lain yang tidak masuk dalam penelitian ini.

\section{Hasil Uji F}

Dari analisa output regresi dapat diketahui nilai F seperti tabel berikut :

Tabel 3

Hasil Uji F

\begin{tabular}{|c|c|c|c|c|c|c|}
\hline \multicolumn{7}{|c|}{ ANOVA $^{b}$} \\
\hline \multicolumn{2}{|c|}{ Model } & $\begin{array}{l}\text { Sum of } \\
\text { Squares }\end{array}$ & df & $\begin{array}{l}\text { Mean } \\
\text { Square }\end{array}$ & $\mathrm{F}$ & Sig. \\
\hline 1 & Regression & 392.346 & 2 & $\begin{array}{r}196.17 \\
3\end{array}$ & $\begin{array}{r}46.78 \\
9\end{array}$ & $.000^{\mathrm{a}}$ \\
\hline & Residual & 117.396 & 28 & 4.193 & & \\
\hline & Total & 509.742 & 30 & & & \\
\hline
\end{tabular}

a. Predictors: (Constant),

$\mathrm{X} 2, \mathrm{X} 1$

b. Dependent Variable: Y

Berdasarkan tabel diatas diperoleh nilai $F_{\text {hitung }}$ sebesar 46,789 dengan menggunakan tingkat keyakinan $95 \%, \alpha=5 \%$ dan df $2(n-k-1)=31-2-1=29(\mathrm{n}$ adalah jumlah data). Dengan demikian hasil diperoleh untuk $\mathrm{F}_{\text {tabel }}$ pada tingkat 28 adalah 3,33. Maka kriteria Kinerja karyawan adalah $\mathrm{F}_{\text {hitung }} 46,789>\mathrm{f}_{\text {tabel }} 3,33$, sehingga $\mathrm{H}_{\mathrm{o}}$ ditolak dan $\mathrm{H}_{\mathrm{a}}$ dterima yang berarti terdapat pengaruh secara simultan antara Motivasi dan Disiplin kerja terhadap Kinerja karyawan PT.PP London Sumatera Indonesia Tbk. Bukit Hijau Estate Kecamatan Rawas Ilir Kabupaten Musi Rawas Utara.

\section{PEMBAHASAN}

Berdasarkan deskripsi di atas secara nyata dapat disimpulkan bahwa terdapat hubungan positif antara motivasi dan disiplin kerja dengan kinerja karyawan Pada PT.PP London Sumatera Indonesia Tbk. Bukit Hijau Estate Kecamatan Rawas Ilir Kabupaten Musi Rawas Utara. . Artinya semakin tinggi angka skor untuk motivasi dan disiplin kerja, semakin tinggi juga tingkat kinerja karyawan. 
Berdasarkan hasil pengujian yang dilakukan diperoleh hasil perhitungan dengan persamaan regresi linier berganda dengan persamaan $\quad \mathrm{Y}=10,428+0,349 \mathrm{X}_{1}+$ $0,382 \mathrm{X}_{2}$. Nilai konstanta sebesar $\mathrm{a}=10,428$ adalah bilangan konstanta yang berarti apabila variabel bebas yaitu $\mathrm{X}_{1}$ (Motivasi) dan $\mathrm{X}_{2}$ (Disiplin Kerja) sama dengan nol, maka besarnya variabel Y (Kinerja karyawan) adalah 10,428. Dengan kata lain jika variabel bebas (Motivasi dan Disiplin Kerja) nilainya dianggap nol berarti besarnya variabel terpengaruh (Kinerja karyawan) adalah sebesar 10,428. $b_{1}=0,349$ adalah besarnya koefisien regresi variabel bebas $\mathrm{X}_{1}$ (Motivasi), yang berarti setiap peningkatan (penambahan) variabel $\mathrm{X}_{1}$ (Motivasi) akan meningkatkan variabel terikat $\mathrm{Y}$ (Kinerja) sebesar 0,349. Jika variabel Motivasi cenderungan meningkat maka Kinerja karyawan akan meningkat dan sebaliknya. b2 =0,382 adalah besarnya koefisien regresi variabel bebas $\mathrm{X}_{2}$ (Disiplin Kerja), yang berarti setiap peningkatan (penambahan) variabel $\mathrm{X}_{2}$ (Disiplin Kerja) akan meningkatkan variabel terikat Y (Kinerja karyawan) sebesar 0,382 .

Jadi penelitian yang dilakukan Marpaung (2014), mempunyai persamaan dengan penelitian yang akan dilakukan oleh penulis yaitu terdiri dari jenis penelitian yang sama kuantitatif, variabel yang digunakan yaitu terdiri dari variabel bebas moivasi dan disiplin kerja variabel terikat yaitu kinerja. jenis data yang digunakan yaitu data primer dan sekunder, dan teknik analisis data yang sama. Dan perbedaannya yaitu tempat penelitian yang dilakukan di Rumah Sakit sedangkan penelitian yang dilakukan oleh penulis yaitu bertempat di sebuah perusahaan.

Berdasarkan temuan ini, maka dapat disimpulkan bahwa terdapat persamaan dan perbedaan dari kedua penelitian tersebut. Persamaannya terdiri dari jenis penelitian, variabel yang dipakai, jenis data, dan teknik analisis data. Sedangkan perbedaanya yaitu dari tempat penelitian.

\section{SIMPULAN}

Berdasarkan dari hasil perhitungan nilai $\mathrm{F}$, diperoleh nilai $\mathrm{F}_{\text {hitung }}$ sebesar 46,789 dengan menggunakan tingkat keyakinan 95\%, $\alpha=5 \%$ dan df $2(n-k-1)=31-2-$ $1=29$ ( $\mathrm{n}$ adalah jumlah data). Dengan demikian hasil diperoleh untuk $\mathrm{F}_{\text {tabel }}$ pada tingkat 28 adalah 3,33. Maka kriteria Kinerja karyawan adalah $F_{\text {hitung }} 46,789>f_{\text {tabel }}$ 3,33, sehingga $\mathrm{H}_{\mathrm{o}}$ ditolak dan $\mathrm{H}_{\mathrm{a}}$ dterima yang berarti terdapat pengaruh secara simultan 
antara Motivasi dan Disiplin kerja terhadap Kinerja karyawan PT.PP London Sumatera Indonesia Tbk. Bukit Hijau Estate Kecamatan Rawas Ilir Kabupaten Musi Rawas Utara.

\section{DAFTAR PUSTAKA}

Doni Juni Priansa. (2016). Perencanaan dan Pengembangan SDM. Cetakan ke-2. Bandung : Alfabeta.

Hamali Yusuf Arif. (2016). Pemahaman Manajemen Sumber Daya Manusia. Cetakan. 1. Yogyakarta : CAPS (Center For Acedemic Publishing Service).

Iga marwani Marpaung, (2014). Jurnal Administrasi Bisnis. Motivasi, Disiplin Kerja, Kinerja Karyawan. (JAB)| 15(2), (1-8).

Irham Fahmi. (2014). Manajemen, Teori, Kasus, dan Solusi. Cetakan ke-3. Bandung. Penerbit : Alfabeta.

Siagian Sondang. P. (2013). Manajemen Sumber Daya Manusia. Edisi. 1. Cetakan ke dua puluh satu. Jakarta : Bumi Askara.

Sinambela Poltak Lijan. (2012). Kinerja Pegawai Teori Pengukuran Dan Implikasi. Edisi Pertama. Cetakan Pertama. Yogyakarta : Graha Ilmu.

Sugiyono. (2014). Metode Penelitian Manajemen. Cetakan ke-5. Bandung : Alfabeta Wibowo. (2012). Manajemen Kinerja. Cetakan ke-4. Jakarta : RajaGrainido Perseda. 